\title{
Maps and Illustrations
}

MAPS

Iroquoia and its frontiers, ca. 1670 s ${ }_{1} 6$

Iroquoia, ca. 167 os 19

Visscher's New Netherland in $1655 \quad 122-23$

Du Creux's New France, 1660 2Io-II

Iroquois country and plan of forts on River Richelieu ${ }_{21} 6$

Bressani's New France, $1657 \quad 242-43$

\section{ILLUSTRATIONS}

The First Woman cast through a hole in the Sky-world 23

Iroquoian women's work 29

Huron deer hunt 39

Palisaded Iroquoian town under siege $5^{I}$

Howlett Hill archaeological site 55

Aerial view of excavations at the Howlett Hill site 56

An Iroquois longhouse 57

The Mohawk village of Caughnawaga $6 I$

Mohawk elm bark feast bowl 66 
x Maps and Illustrations

Woven reed armor of the Iroquois 70

Iroquois defeat in encounter with Champlain in 160973

Reciting the laws of the Confederacy 99

The Baker, by Job Adriaensz Berckheyde $15 I$

Sychnecta 173

Marie de l'Incarnation ${ }_{1} 84$ 